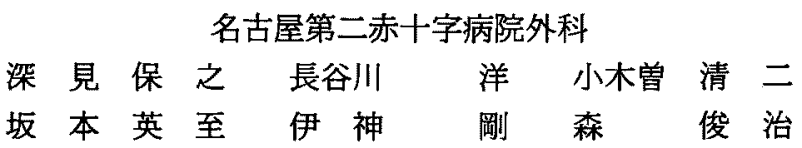

症例 1 は45歳, 男性. ピストルで左側腹部を撃たれ救急外来に搬送された，血圧は触 診で $60 \mathrm{mmHg}$, 左側腹部に射入創, 右側腹部の皮下に銃弾を触知した. 開腹すると, S 状 結腸間膜と空腸間膜が損偒を受け, 空腸と上行結腸が穿孔していた，空腸部分切除，回 盲部切除術を施行し, 術後28病日に退院した。

症例 2 は41墄, 男性. ピストルで数発撃たれ受傷し来院した. 右腋窝に貫通銃創, 腰 部加左腹部に抜ける貫通銃創, 左大腿に貫通銃創, 右腹部に盲管銃創, 左下派に盲管 銃創を認め, 開腹し空腸部分切除, 回盲部切除術を施行した。 また腹壁と左下腿の弾丸 は摘出した。術後45病日に退院した。

銃創は本邦においては稀であるが，今後增加することが予想される，腹部銃創による 腹腔内蔵器損傷が疑われる場合には，迅速な手術決定が必要であると思われた。

索引用語：腹部外傷, 銃創

はじめに

銃器による外傷は現在わが国においては幸いにして 稀である。それゆえ銃創症例に対する治療経験が豊富 な医師は少ない，今回われわれは救命しえた腹部銃創 の 2 例を経験したので若干の文献的考察を加えて報告 する.

\section{症例}

症例 $1: 45$ 葴, 男性.

主訴：銃弾による腹部外傷。

既往歴：特記すべきことなし.

現病歴：2000年12月 1 日午前 0 時 21 分, 強盗に至近 距離から拳銃で腹部を㧘たれ被弾した。午前 0 時54分, 救急車で当院救急外来へ搬送された。

入院時現症：血圧は触診で $60 \mathrm{mmHg}$, 顔面菅白で四 肢冷感あり。左側腹部に約 $6 \mathrm{~mm}$ の銃痕を認め, 右側 腹部皮下に弾丸を触知した(図 $1 \mathrm{a})$ ）意識は清明であ ったが，やがて傾眠傾问となった。

入院時検查所見 : WBC $11,200 / \mathrm{mm}^{3}, \mathrm{RBC} 425 \times$ $10^{4} / \mathrm{mm}^{3}$, Hb $15.0 \mathrm{~g} / \mathrm{dl}$, Hct $40.1 \%$, Plt $23.5 \times 10^{4} /$

2003年 3 月 17 日受付 2003 年 6 月11日採用

〈所属施設住所〉

广466-8650 名古屋市昭和区妙見町 $2-9$ $\mathrm{mm}^{3}, \mathrm{CK} 210 \mathrm{IU} / \mathrm{l}$, その他特に異常を認めなかったが， 手術直前の $\mathrm{Hb}$ は6.0g/dl まで低下していた。

患者の意識は傾眠傾向であったが何とか手術の同意 を得た。また家族は九州であったが電話で手術の同意 を得た. 同時に䁍器損傷の程度を確認するため, CT 検 亘を施行した。

腹部造影 CT 検查：左側腹部の射入部に散布された 鉛片が高陰影像として認められ(図 $2 \mathrm{a}$ ), 右側腹部の 射出部に弾丸による高陰影像を認めた（図 2 b). 腸間 膜内に造影剂の血管外漏出像と腹水貯留を認めた。明 らかな大血管損傷は認めなかった。

大量輸血の準備を行い，当院搬送約 1 時間後に緊急 手術を開始した。

手術所見：開腹すると腹腔内は大量出血しており， 空腸間膜および $\mathrm{S}$ 状結腸間膜に損傷，出血部位を認め た。同部位を止血，修復した。さらに上行結腸と空腸 に穿孔部を認め(図 3)，回盲部切除，空腸部分切除術 を施行した。右側腹部に触知していた弾丸（図 1 b) を摘出し，洗浄ドレナージ後手術を終了した。術中の 総出血量は $8,520 \mathrm{ml}$ であった。

手術よりおよそ10時間後突然吐血が出現し, 再開腹 手術を施行した，空腸吻合部付近の腸管内に出血を認 めたので，同部を切除，吻合した. 


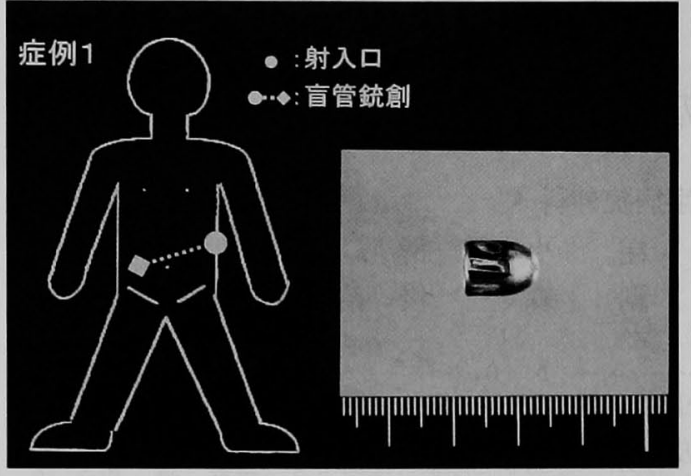

a

b

図 1 症例 1 ：シェーマ（a）と摘出弾丸（b).

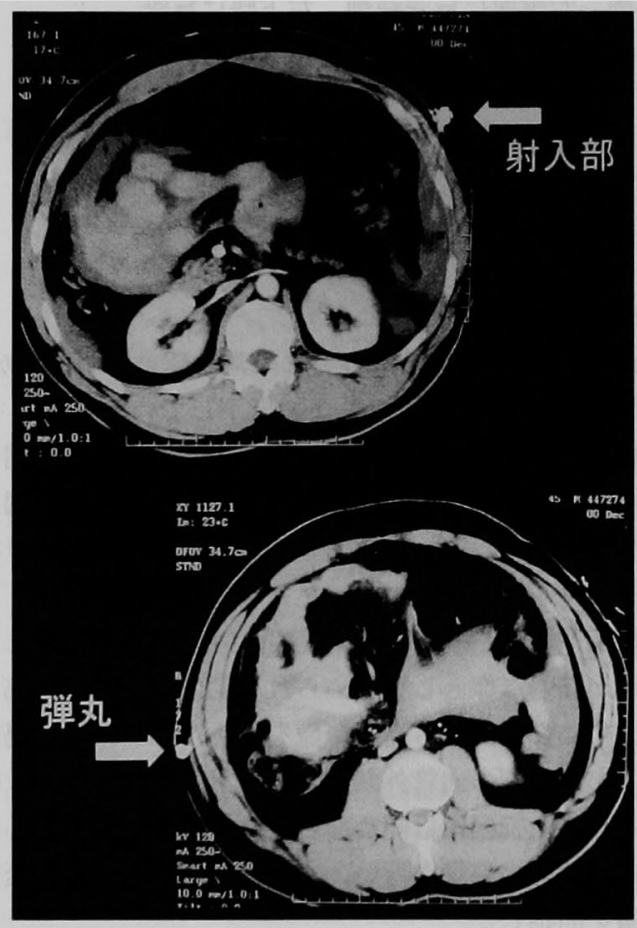

図 2 腹部造影 CT 検查：左側腹部に射入部 (a), 右側腹部皮下に弾丸を認めた（b). 腸間膜内に造 影埨の血管外漏出像と腹水貯留を認めた。 $\frac{\mathrm{a}}{\mathrm{b}}$

術後経過：術後経過は良好で, 術後28病日に退院し た.

症例 $2 ： 41$ 歳, 男性.

主訴：銃弾による腹部，下肢外傷.

既往歴：胸部，左下腿に銃創歴あり。

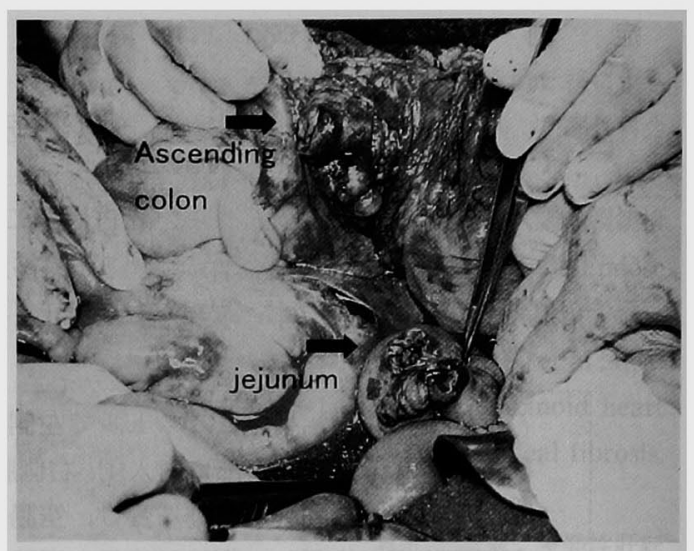

図 3 手術所見 (症例 1 ) ：上行結腸と空腸に穿孔部を認 めた.

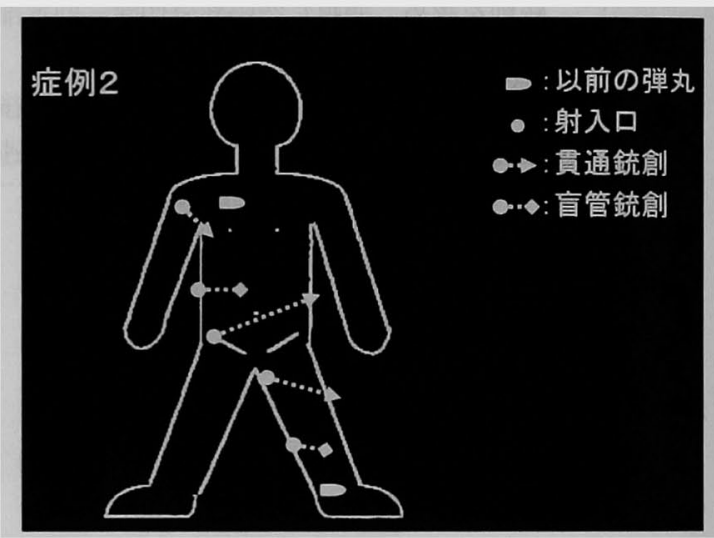

図4症例 2 (シェーマ)：右方から被弾したと予想され， 右胸部と左下駺に以前の弾丸があり, 今回は右腋窝に貫 通創, 右腹部に忘管創, 腰部から左腹部に抜ける貫通創, 左大腿に貣通創，左下腿に盲管創を認めた。

現病歴：2000年12月16日深夜，イラン人同士の抗争 の際拳銃で数発擊たれ，仲間の車で当院救急外来に来 院した．独歩にて診察室に入り倒れ込んだ。

入院時現症：収縮期血圧は $140 \mathrm{mmHg}$, 脈拍 $72 / \mathrm{min}$, 意識清明でしきりに“ピストル”と繰り返していた。 3 力所の貫通銃創と, 2 力所の盲管銃創を認めた. 右 万から被弾したと予想され，右胸部と左下駺に以前の 弾丸があり, 今回は右腋窝に貫通創, 右腹部に盲管創, 腰部から左腹部に抜ける貫通創，左大腿に貫通創，左 下腿に盲管創を認めた（図 4)。

入院時検查所見 : WBC $11,000 / \mathrm{mm}^{3}, \mathrm{RBC} 563 \times$ $10^{4} / \mathrm{mm}^{3}, \mathrm{Hb} 16.5 \mathrm{mg} / \mathrm{dl}$, Hct $46.8 \%$, Plt $29.5 \times 10^{4} /$ 


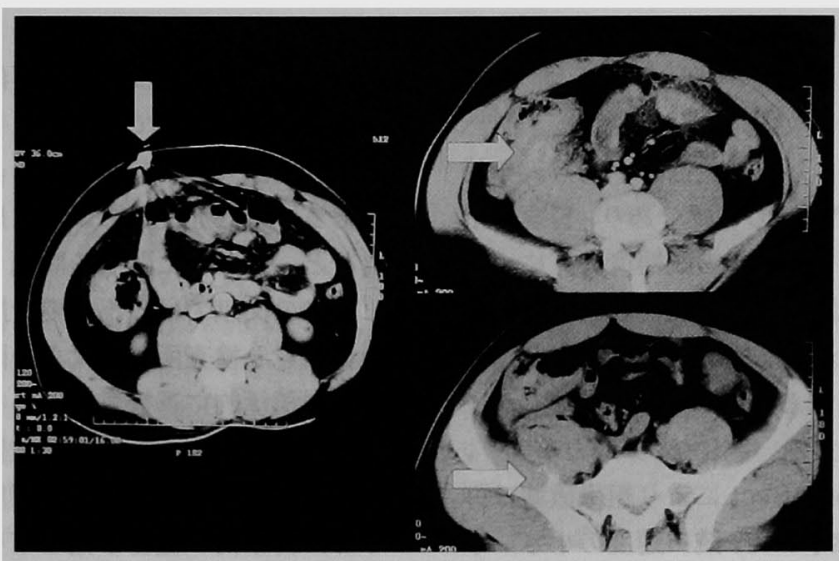

図 5 腹部造影 CT 検查：触知していた弾丸が描出された (a). 右腰 部から腸骨を貫き，その骨片が腹腔側へ広がっており（b)，回盲部 付近に造影㘊の血管外漏出像, 腹水貯留を認めた（c）. $\quad a \mid \frac{b}{c}$

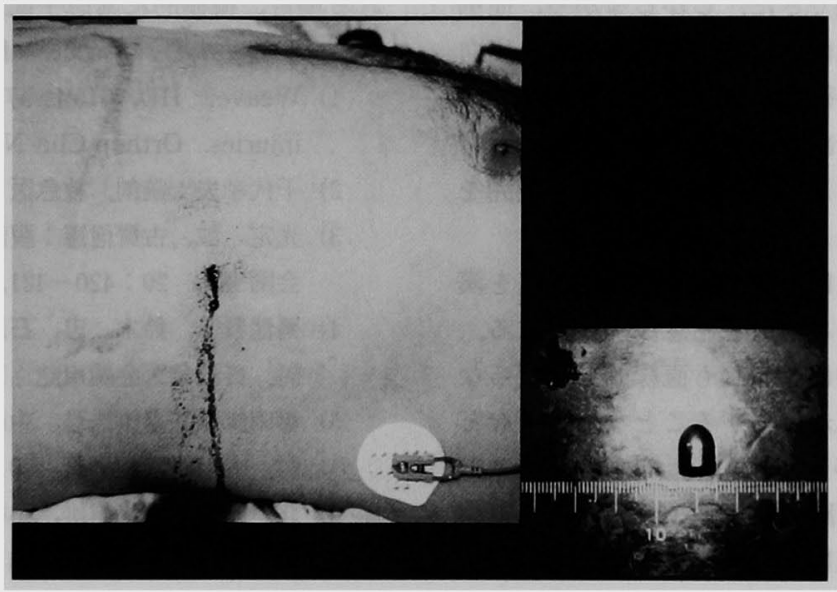

a

b

図 6 手術所見（症例 2）：a）腰部から左腹部に抜ける貫通創，b） 摘出された弾丸。

$\mathrm{mm}^{3}, \mathrm{CK} 968 \mathrm{IU} / \mathrm{l}$, その他特に異常を認めなかったが, 手術直前の $\mathrm{Hb} は 11.7 \mathrm{mg} / \mathrm{dl}$ まで低下していた。

腹部造影 CT 検查：触知していた弾丸が描出され た. 右腰部から腸骨を貫き，その骨片が腹暌側へ広が つており，回盲部付近に造影剤の血管外漏出像，腹水 貯留を認めた(図 5 )。明らかな大血管損傷は認めなか った.

患者は日本語，英語など通じず同意を得るための説 明は十分ではなかったが，人道上からも救命のため, 当院搬送約 1 時間 20 分後, 緊急手術を施行した。
手術所見：開腹すると污染した腹水を多量に認め た．右腸骨を貫いた弾丸が上行結腸を貫き，小腸に 2 力所穿孔部位を認めた．腸管の獎膜に一部熱傷を認め た. 回盲部切除と小腸部分切除術を施行した。また腹 壁と左下腿の弾丸を摘出した(図 6 )。腸間膜の損傷は 認めなかった。術野に明らかな骨片を認めなかった。 洗浄ドレナージ後手術を終了した，術中の総出血量は $750 \mathrm{ml}$ であった。

術後経過：縫合不全を合併したが経過は良好て, 術 後45病日に留置所へ搬送された。 入院中は警察官が警 
備を務め, 多額の医療費は未納のままであるなど犯罪 者に対する医療の問題点も多かった。

\section{考 察}

銃創による死者が年間 2 万人，負傷者が 20 万人を越 える”米国と比べ，本邦では亟めて稀であり，警察庁生 活安全局銃器対策課の『平成14年の銃器情勢」によれ ば，死者が年間 24 人，負傷者 34 人と報告されている。 銃創は比較的重篤な症例が多く組織損傷度は, 銃弾の 重量と銃口速度で決定されるといわれている2). ライ フル銃などの銃口速度の大きい銃創は, 穿通力が強く, shock wave や cavitation effectにより組織破壊は弾

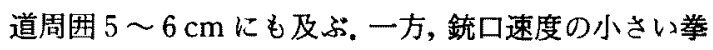
銃などによる銃創は弾道周囲の組織損賃は比較的小範 囲に留まる場合が多い3)-5). 本症例に扔いては, 症例 1 で拳銃一発, 症例 2 で拳銃数発と 2 例とも拳銃創であ り，損傷範囲は広範でなく，大血管損傷も伴わなかっ たため, 救命することができた。しかしながら, 症例 1 では手術から10時間後に遅発性腸管損偒による出血

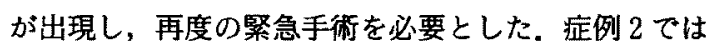
腸管奬膜に熱傷を認め, 部分切除を追加したが, 縫合 不全を合併した，銃創による腸管損傷の程度と範囲を 術中に正確に判断することの難しさを痛感した。

銃創初揨時には, 射入口と射出口を確認し創路を漠 然と推定し, 被弾している弾数も注意深く検索する. ただし，銃創による創路は必ずしも直線的とは限らな い. 症例 1 のように弾丸が貫通することなく皮下など に留まっている場合も多い6). また症例 2 のように数 発被弾している場合, 創路の把握や損偒臟器の特定は 困難な場合が多い. Vital sing の測定と一般血液生化 学検查を行いつつ, 可能な限りレントゲン検查, 造影 $\mathrm{CT}$ 検查を行い, 大血管損傷の有無, 蔵器損偒の程度, 創路の推定を急ぐことが重要である778). 症例 1,2 と もに造影 CT 恰查が有用であり, 損傷缄器の予想が可 能であった。損傷蔵器の頻度は小腸, 大腸の順に多 ( ${ }^{99}$. 低速弾丸による大腸損傷で, 腹腔内污染が少な く, 受傷後 6 時間以内に手術開始した場合は, 本症例 のように一次的閉腹も可能でるる?.

銃規制されている本邦において，銃創患者は特殊な 状況下で着院する場合が多い. 症例 1 で梁夜の強盗 事件で, 無保険, 着院後意識は次第に傾眠傾向となり, 家族は遠方であった。症例 2 では, 深夜で患者は外国
人犯罪者, コミュニケーションをとるのも困難であっ た.このような状況下で, 可能な限りのインフォーム ドコンセントを得て, 迅速に手術に至り救命するため には, 医療スタッフ全員のチームワークが非常に重要 である．また症例 2 のうに患者が外国人犯罪者の場 合など，医療費に関する問題も無視できない，

欧米の文献では，不必要な開腹手術を避けるため, 身体所見と検查所見に大きな問題がなければ, 保存的 治療を積極的に選択するという文献もある10).しかし， 本邦に扔いて銃創症例の経験豊富な外科医は極めて少 なく, 自験例でも特に損傷程度の正確な鿉中評価蜼 しく，再手術や縫合不全などを生じた，銃㧞症例に遭 遇し, 少しでも腹望内臓器損傷の可能性があれば, 緊 急手術を行うべきである.

\section{結 語}

腹部銃創の 2 例を経験した。腹腔内臓器損傷が疑わ れる場合，積極的に緊急手術を考虑すべきである。

\section{文 献}

1) Weaver $\mathrm{HD}$, Hansraj $\mathrm{KK}$ : Gunshot wound injuries. Orthop Clin North Am $26: 1-7,1995$

2）千代孝夫：銃創. 救急医 14:1517-1520，1990

3）光定 誠, 古賀信憲 : 腹部銃創の 3 例. 日救急医 会関東誌 $20: 420-421,1999$

4）菊池恭子, 鉿木 忠, 石川雅健他：銃創症例の検 討. 日救急医会関東誌 $13: 114-115,1992$

5）藤田修弘, 富吉浩雅, 中森 靖他：銃創36例の検 郡. 大阪䇾察病医誌 $20: 3-10,1996$

6）北里試也, 加来信雄, 小林良三地：開放性腹部外 偕の検討。日外賃研会誌 $3: 195-199,1989$

7) 川村光夫, 高橋保博, 楖古親夫他: 緊急手術にて 救命しえた胸腹部貫通銃創の 1 例。胸部外科 $47: 577-579,1994$

8）吉田昌弘, 潟巣 寛, 久保速三他：胸腹部銃創の 1 救命例。日救急医会誌 $7: 720-724,1996$

9）金田英巳, 三浦則正, 大野昭二他：腹部銃創の治 療経験。太田病年報 $22: 53-59,1987$

10) Velmahos GC, Demetriades D, Toutouzas KG, et al: Selective nonoperative management in 1 , 856 patients with abdominal gunshot wounds: should routine laparotomy still be the standard of care? Ann Surg 234:395-403, 2001 


\title{
TWO CASES OF ABDOMINAL GUNSHOT WOUND
}

\author{
Yasuyuki FUKAMI, Hiroshi HASEGAWA, Seiji OGISO, \\ Eiji SAKAMOTO, Tsuyoshi IGAMI and Toshiharu MORI \\ Department of Surgery, Nagoya Daini Red Cross Hospital
}

Patient 1, a 45-year-old man was transferred to the hospital for left abdominal gunshot wound. Blood pressure was $60 \mathrm{mmHg}$, a gunshot wound found in the left lateral region of abdomen. The bullet was palpated in the right lateral region. Upon laparotomy, the sigmoid mesocolon and jejunum ligament were damaged and the jejunum and an ascending colon were perforated.

A partial jejunectomy and an ileocecal excision were performed.

He was discharged from the hospital on the 28th hospital day.

Patient 2, a 41-year-old man was admitted to the hospital because of several abdominal gunshot wounds. Transfix wounds were found in the right armpit, lumbar part to left abdomen, and left thigh. Blindness wounds were found in the right abdomen and left crus.

A partial jejunectomy and an ileocecal excision were performed under laparotomy. We removed the bullets in the abdominal wall and left crus. He was discharged from the hospital on the 45th hospital day. The gunshot wound seems to increase in the near future, though it is still rare in Japan. We think that quick decision-making of operation is required patients who are suspected to have intraabdominal injuries due to abdominal gunshot wounds. 